\title{
The permanency of the state of emergency in Turkey
}

The rise of a constituent power or only a new quality of the state?

\author{
Ece Göztepe
}

(C) Springer Fachmedien Wiesbaden GmbH, ein Teil von Springer Nature 2018

\begin{abstract}
Working on the state of emergency/exception requires inevitably an idea of normality. For the first time the Roman law came up with the idea of ruling the state of exception before the exceptional conditions emerge and the Romans decided to locate the exceptional power beside the normal system. Even the terms and the content of the exceptional powers of the Roman dictators have been changed over time, the separation of their extra-legal powers from the regular system and the system-intern control of these powers stayed the core of the regulations. On the other hand, most of the modern constitutional states have preferred to locate the exceptional, mostly executive powers, within the system and guaranteed a parliamentary and especially judicial control over the use of these constitution-based powers. So, the normative rules on the state of exception in modern constitutional states are still a dependent variable. The state of emergency regimes is seen as a special form of upholding the rule of law principles and are bounded to the status quo with help of the courts.
\end{abstract}

This article examines the evolution of the normative regulations of the state of emergency in Turkey in the light of the jurisprudence of the Turkish Constitutional Court. Despite the constitutional restriction in Article 148 par. 1 that forbids the constitutionality control of the emergency decrees by the Constitutional Court the Turkish Constitution of 1982 could have also been subordinated to the system of modern constitutional states. The article summarizes the interpretation of the restrictive constitutional norms by the Turkish Constitutional Court in the 1990's in a very progressive way. In the second part I analyse the content of the thirty-two state of emergency decrees as of the attempted coup d'état in 15 July 2016 and show the shift from the state of exception regime under the rule of law to the nonrevolutionary constituent power without any legal restrictions. The main subject of

Prof. Dr. E. Göztepe ( $\square)$

Faculty of Law, Bilkent University, Bilkent, Turkey

E-Mail: goztepe@bilkent.edu.tr 
this analysis is to show the "legal revolutionary effect" of the TCC decisions after October 2016 which have abandoned its former concept of the constitutional limits of the emergency regimes and in fact give up its own functional existence and legitimacy within the constitutional system.

\section{Die Permanenz des Ausnahmezustandes in der Türkei}

Der Aufstieg einer verfassungsgebenden Gewalt oder nur eine neue Staatsqualität?

Zusammenfassung Das Nachdenken über den Ausnahmezustand bedingt unvermeidlich die Idee der Normalität. Zunächst brachte das römische Recht die Idee zur Regelung des Ausnahmezustandes vor dem Erscheinen der Ausnahmezustände hervor und platzierte die Ausnahmekompetenzen außerhalb des normalen Systems. Auch wenn die Amtszeit und die Kompetenzen des römischen Diktators sich im Laufe der Zeit änderten, blieb die Unterscheidung zwischen den Ausnahmeregelungen und dem normalen Rechtssystem sowie die systeminterne Kontrolle der Ausnahmekompetenzen das Hauptmerkmal des römischen Systems. Auf der anderen Seite haben die meisten Verfassungsstaaten Ausnahmezustandsregelungen mit erweiterten Exekutivkompetenzen innerhalb des Rechtssystems bevorzugt, die parlamentarischer sowie judikativer Kontrolle unterworfen sind. Somit sind solche Kompetenzen in modernen Verfassungsstaaten immer abhängige Variablen in Bezug auf die reguläre Rechtsordnung. Die Ausnahmezustandsregime werden in dieser Hinsicht als eine spezielle Form zur Aufrechterhaltung des Rechtsstaates betrachtet und sind durch die judikative Kontrolle dem status quo unterworfen.

Dieser Beitrag untersucht die Entwicklung der normativen Regelungen zum Ausnahmezustand in der Türkei unter Bezugnahme der Rechtsprechung des Türkischen Verfassungsgerichts. Auch wenn Art. 148 Abs. 1 der Verfassung die Verfassungsmäßigkeitskontrolle von Ausnahmerechtsverordnungen verbietet, kann die Türkische Verfassung von 1982 zu modernen Verfassungsstaaten gezählt werden. Der Beitrag fasst die progressive Auslegung der genannten restriktiven Verfassungsregelungen durch das Türkische Verfassungsgericht in den 1990er Jahren zusammen. Im zweiten Teil wird der Übergang zu einer weniger progressiven Rechtsprechung ab 2015 erklärt. Im Anschluss wird der Rückzug vom Ausnahmezustand im Rahmen des Rechtsstaates zu einer nicht-revolutionären verfassungsgebenden Gewalt ohne normative Schranken anhand der dreiundzwanzig Ausnahmerechtsverordnungen nach dem versuchten Putsch am 15. Juli 2016 analysiert. Das Hauptanliegen dieser Analyse liegt darin, die Wirkung der verfassungsgerichtlichen Rechtsprechung nach Oktober 2016 zu zeigen, die an einer „legalen Revolution“ grenzt und den Ausnahmezustand seinen verfassungsrechtlichen Grenzen entledigt hat. Im Endeffekt kommt dies der Selbstaufgabe der funktionalen Existenz und Legitimität des Verfassungsgerichts im Rechtssystem gleich. 


\section{Introduction}

The term of exception requires inevitably an idea of normality and the regular. But the definition of exception in a political manner has differed over the centuries all over the world. The reason lies in the fact that every thinker has used the empirical evidence of his time (political and economic crises, wars, threats from outside, revolutions, etc.) for his theory, and has pursued the problems of his time from a concrete framework. Since the Roman Republic, thinking about the state of emergency has been based on factuality, from which the theory follows. Every ground for uncertainty and disorder in history has created more theories and ideas about the state of emergency. Therefore, it is hardly possible for contemporary scholarship to fully subscribe to a theory of the great thinkers and to classify the empiricism of the present problems according to this theory. Despite this multiplicity of fact-based theories, the Ancient Roman dictatorship has been the most useful orientation point in the attempt at modelling, beginning with St. Augustin to Machiavelli, Althusius, Spinoza, Locke, Montesquieu, Rousseau, Kant to Hegel.

The Roman legal order made a distinction between the state of normalcy and the state of an emergency regime. Detailed regulations were drafted in the following subjects: Determination of the state of emergency, assignment of an individual (dictator) to work towards returning to the state of normalcy (status quo ante), limiting the duration of the emergency regime and the extraordinary power given ${ }^{1}$. Today this regimentation is still shaping emergency regulations in modern constitutional regimes (Ferejohn and Pasquino 2004, p. 210 ff.). To mention only some of the many classifications, Günter Frankenberg differentiates between the models "Machiavelli", "Hobbes" and "Locke" (2010, p. $20 \mathrm{ff}$.): While the "Machiavellian model" focuses on obtaining and defending authority, the distinction between state of normalcy and emergency is not clear. The Prince is not limited by law and ethical principles, so that any limitations on governmental laws or measures are obsolete. The "model Hobbes" can be characterized as a transitional period between Machiavelli and the modern constitutional state in Lockean terms. In conjunction with the social contract in regards to ensuring security, internal and external threats and the measures concerning them became a matter of sovereignty.

As the final step in the Lockean model, emergency regimes are integrated into the legal framework of the constitutional state. There is tension between the normalcy of the normative and the extra-legality of the factual. Predictions concerning causes of the state of the emergency are made beforehand and the precautions and authorized bodies are determined through the constitution and legislation. The aim of these regulations is to prevent the administrative authority from using extrajudicial means and giving themselves special power in the legal framework, thereby keeping them under control. Locke defines the state of emergency powers as "the power to act according to discretion for the public good, without the prescription of the law and sometimes even against it, is that which is called prerogative" $(1823, \S 160)$. Locke puts prerogative in the hands of the "wisest and best princes", but does not consider

\footnotetext{
1 "The classical Roman dictatorship was a conservative-preservative-stabilizing institution, not a transfor-
} mative one ...” (Pasquino 2013, p. 148). 
the dangers of misuse of this discretionary power since they would "act for the benefit of the community and the public good" (1823, §161, 165). Thus, Locke's "prerogative" is considered the first modern instrument of crisis intervention, which is today regarded as a standard in modern statehood. The prerogative allows the maintenance of the existing norm structure and transfers the executive strengthened powers to established institutions/officials. Thereby the normality of the state is continued in other areas (Lemke 2017, p. 81).

Even though Locke presupposes the predictability of the state of emergency and provides for an internal system of regulation, the fundamental question brilliantly formulated by Carl J. Friedrich remains unanswered: "Can you justify the violation of the law, when the survival of the legal order is at stake?" (1957, p. 14). This dilemma actually already arose with the Romans. Sulla, after being "elected" by the people became a dictator. Montesquieu noted the insignificance of Sulla's gesture in giving up the dictatorship and submitting to the Roman people. Because Sulla " "had already done so many things to undermine Roman virtue that his returning of the power to the people (because he did not wish to rule over slaves) was an empty gesture. He had done things which made it "impossible for Rome to conserve her liberty", (Friedrich 1957, p. 50). The distinction between the traditional Roman dictatorship and Sulla's extraordinary constituent powers (Straumann 2016, p. 84) gives us today, the possibility to qualify and overthink the current prerogative measures within constitutional states. So the question is whether a constitutional state can normatively and factually regulate such an extra-constitutional exception clause.

In the following, I will examine this question using the example of Turkey and try to answer the question as to which institutional guarantees a constitutional state can build and what its effective limits are. I will first present the constitutional framework of the state of emergency regime and its interpretation by the Turkish Constitutional Court (2). Through this, the importance of the institutional structures of a constitutional state becomes clear. Subsequently, the first attempt to break through this set normative structure is presented (3) in order to explain the final stage of an unconstitutional state (4).

\section{The Normative Framework of the State of Emergency Regime and Its Interpretation by the Constitutional Court ${ }^{2}$}

Turkey, a nation which has existed beneath the shadow of an emergency state from the date of its founding in 1923, has extensive normative regulations concerning the subject. These normative regulations, which can be characterised as a constitution within a constitution, can be considered as principle derogations of the constitu-

\footnotetext{
2 Following the fundamental constitutional amendment of 16.04.2017, the provisions of which having been in force since 9 July 2018, the Council of Ministers was abolished and the powers of the Council of Ministers were transferred to the President. Additionally, martial law (sıkıyönetim) was abolished and the grounds for calling the state of emergency were summarized in one article.

However, since all the measures worked through in this article were taken under the old constitution and the fundamental question of the institutional guarantees and the self-abandonment of the institutions are also subject to new constitutional provisions, the state of emergency regulations applicable before 9 July 2018 are cited. Namely Articles 15, 119 to 122 and 148.
} 
tional norms. Relevant articles of the 1982 Constitution on the state of emergency are Art. 15, 119 to 122, 148 par. 1. Emergency powers are foreseen for two reasons: Firstly, in the event of natural disaster, dangerous disease epidemics or serious economic crisis and secondly, for reasons of national security and serious deterioration of public order. An interesting fact is that during the period of the 1982 Constitution, although there were numerous economic crises and natural disasters, a state of emergency was never declared referring to article 119. A state of emergency is mainly a matter of national security for Turkey. A security threat is handled with gradually increasing severity from a state of emergency, martial law, mobilization and finally a state of war. The conditions and measures regarding the emergency regime are regulated under the Constitution with a derogatory perspective resulting in partial suspension of the Constitution in force. In times of war, mobilization, martial law, or a state of emergency, the exercising of fundamental rights and freedoms may be partially or entirely suspended, or measures derogating the guarantees embodied in the Constitution may be taken to the extent required by the exigencies of the situation, as long as obligations under international law are not violated (Art. 15 par. 1). Even under the circumstances indicated in the first paragraph, the individual's right to life, the integrity of his/her corporeal and spiritual existence shall be inviolable except where death occurs through acts in conformity with law of war; no one shall be compelled to reveal his/her religion, conscience, thought or opinion, nor be accused on account of them; offences and penalties shall not be made retroactively; nor shall anyone be assumed guilty until so proven by a court ruling (Art. 15 par. 2). This provision implies that during the duration of a state of emergency constitutional rights are largely suspended, for the protection of the constitutional order, but the extraconstitutional order should be in effect for a brief period with the aim of returning to normalcy.

Constitutional regulations authorize the legislator to determine the legal framework of the emergency regime. According to article 121 par. 2, "the financial, material and labour obligations which are to be imposed on citizens in the event of the declaration of a state of emergency under Article 119 and the manner in which fundamental rights and freedoms shall be restricted or suspended in line with the principles of Article 15, how and by what means the measures necessitated by the situation shall be taken, what sorts of powers shall be conferred on public servants, what kinds of changes shall be made in the status of officials as long as they are applicable to each kind of state of emergency separately, and the extraordinary administration procedures, shall be regulated by the Act on State of Emergency". The legislator fulfilled the liability first by enacting the 2935 Act on State of Emergency and the 1402 Act on Martial Law. In Turkish law these acts are named "standby laws". They are implemented only when the emergency regime is in effect according to laws and they are on "standby" in periods of normalcy.

Regarding the authoritative bodies, in line with the Ancient Roman tradition, the body deciding on the state of emergency and the body controlling this decision is separated under law. The body determining if there is a state of emergency is the Council of Ministers meeting first under the chairpersonship of the President of the Republic. Then this decision is published in the Official Gazette and immediately submitted to the Grand National Assembly of Turkey for approval. The Grand 
National Assembly may alter the duration of the state of emergency, may extend the period up to a maximum of four months each time at the request of the Council of Ministers, or may lift the state of emergency. Thus a political decision is controlled by another political body. But one should keep in mind that in a parliamentarian system with a one-party government the political control is not effective. Also, just like in Ancient Rome, the state of emergency is limited to a specific timeframe and location. Tools which are employed in these situations are closely related to the objective. The competences of the Council of Ministers should aim to abolish the reasons for the state of emergency in order to establish the status quo ante. The Council of Ministers may issue decrees having the force of law on matters necessitated by the state of emergency. Even these decrees should be submitted to the Grand National Assembly of Turkey on the same day for approval.

The last constitutional provision concerns judicial control of the measures taken during the state of emergency. The most significant issues regarding the state of emergency regulated normatively in constitutional democracies are the constitutional/legislative regulations, and controlling the authority given according to the boundaries defined by these regulations. The foremost paradox of the Lockean model is acting beyond the constitution but within the boundaries set by the constitution during the return to the status quo ante. So, inevitably the question arises "How to determine if there is an inclination towards a sovereign dictatorship from a commissarial dictatorship and to take measures to prevent it" 3 . In countries with a constitutional court, the most sensible approach is that this task should be undertaken by the judicial body. But Article 148 par. 1 replaces the constitutional review with the political control, so only the majority of the Grand Assembly has the formal control over the emergency measures. Art. 148 par. 1 states that "Decrees having the force of law issued during a state of emergency, martial law or in time of war shall not be brought before the Constitutional Court alleging their unconstitutionality as to form or substance". Summing up, the Turkish Constitution following apparently the Lockean model, distributes the emergency powers between the legislative and the executive with a power concentration in favour of the latter, but excludes judicial control by the Constitutional Court. So we should ask whether this uncontrolled power is compatible with the spirit and logic of the Lockean model.

Legal restrictions on the constitutional emergency power regime have been established by four essential Constitutional Court decisions ${ }^{4}$ in 1990, 1991 and 2003. In these decisions the obligatory characteristics and logical results of the state of emergency are explained, constitutional principles are interpreted and the limits of an emergency regime in a constitutional state are strengthened. These principles could be briefly summarized as follows:

\footnotetext{
${ }^{3}$ See for the differentiation of the terms commissarial and sovereign dictatorship (Schmitt 1994; Nippel 2011, p. $105 \mathrm{ff}$.$) .$

${ }^{4}$ E. (reference number) 1990/25, K. (decision number) 1991/1 (10.1.1991); E. 1991/6, K. 1991/20 (3.7.1991), in: AYMK, Vol. 27/1, S. 65-129 und S. 375-421, respectively; E. 1992/30, K. 1992/36 (26.5.1992), in: Vol. 29/1, S. (155-160); E. 2003/28, K. 2003/42 (22.5.2003), in: Vol. 40/1, S. 92-103.
} 
- In a constitutional state, the emergency regime is not an arbitrary, lawless regime. It is a rule of law regime, limited with the constitutional provisions and the law in general. It stands under the control of the legislative as well as the judicial power ${ }^{5}$.

- Its aim is to protect the ordinary law order with means of extraordinary measures, but always within the limits of law6

- Emergency decrees of the executive power should not exceed the limits of the aim of the proclamation of the state of emergency. They are allowed only to regulate operative matters in terms of state of emergency ${ }^{7}$.

- The general laws cannot be amended with emergency decrees since they lose their validity after the end of the state of emergency regime. The executive may only act with measures, but not with general regulations ${ }^{8}$.

- Emergency decrees only prevail to the regions that state of emergency has been declared in, for the specified state of emergency period. The objective is to resolve the cause of the state of emergency9.

- Even though the Constitution excludes the emergency decrees from judicial control, the Constitutional Court is authorised to determine the characteristics of them, meaning if they are actually in the scope of the state of emergency. Otherwise an extra-legal area could be established ${ }^{10}$.

- During the judicial control, not only the Articles 119 to 122 provisions, but the Constitutional provisions as a whole have to be taken into consideration ${ }^{11}$.

In accordance with these principles, the Constitutional Court annulled specific emergency decrees determining that they had exceeded the purpose, location or the time frame of the state of emergency regime and subjected the state of emergency to constitutional judicial review.

\section{Preliminary Cases to Lift Break-Through the Normative Framework and the Jurisprudence of the Constitutional Court}

The state of emergency is regulated under the Constitution, where laws regulating special measures regarding the state of emergency also exist. As the controlling political body, the legislative body's prerogatives towards the emergency regime are regulated normatively, in regards to under which circumstances, by which body and for how long the state of emergency shall be declared. If the relevant state of emergency laws are examined, it can be seen that the measures to be taken regarding the reason for the state of emergency are written in detail (e.g. monetary expense, property restrictions, liability to work; restriction of freedom of movement; media

\footnotetext{
5 E. 1990/25, S. 92-108.; E. 1991/6, S. 390-411.

${ }^{6}$ E. $1990 / 25$, S. 93 ; E. 1991/6, S. 390-397.

7 E. $1990 / 25$, S. 98 ; E. 1991/6, S. 392-407; E. 2003/28, S. 98.

${ }^{8}$ E. 1991/6, S. 399-412.

9 E. 1990/25, S. 100-107; E. 1991/6, S. 397-414; E. 1992/30, S. 158.

10 E. 1990/25, S. 100-105.; E. 1991/6, S. 398-403; E. 2003/28, S. 98.

11 E. 1990/25, S. 107; E. 1991/6, S. 412; E. 2003/28, S. 99.
} 
control etc.). Also curfew measures are granted under two laws. Although these laws do not specify the maximum period of time, limitations or prohibitions on going onto the street are mentioned. However, when these measures are examined the stress can be seen on the phrase "specific time". Thus, after the 12 September 1980 coup d'état, only a night-time curfew (0:00-05:00a.m.) was implemented and the longest curfew occurred on 29 September 1980 in Malatya for 33.5 h, after an explosion.

In autumn 2014, semi-violent protests took place in many South Eastern cities of Turkey, especially Diyarbakır, Batman, Mardin and Van in support of the terror organization PKK members battling against ISIS in Kobane within Syrian territory and protesting Turkey's ISIS policy. In response, the "governors" declared curfew measures "until a further order is made". In consideration of the abovementioned explanations, this new application constituted an apparent contradiction to existing normative regulations and an exception to the former Constitutional Court case law. Previously unobserved in the history of Turkey, in terms of their duration and intensiveness, these declared curfews formed an apparent intervention to the freedom of travel and residence regulated under Article $23^{12}$ and to personal freedom and security regulated under Article 19 of the Constitution. Furthermore, restriction of the fundamental rights and freedoms is only possible with a formal and substantive law, regarding Article 13 of the Constitution.

But addressing the legal basis of these emergency measures, under normal circumstances, when there is a threat to public order, the correct action to be taken should be to arrange a meeting of the Council of Ministers under the chairpersonship of the President of the Republic, after consultation with the National Security Council, following the declaration of the state of emergency in the mentioned regions, regarding article 120 of the Constitution. After this decision of declaration, referral to the measures stated under the Act on State of Emergency is possible. Under this Act, it is stated that these measures are to be taken by the governors. But in fact, the Council of Ministers did not declare a state of emergency before the curfews took place from October 2014 on, including the declaration of curfews in 7 cities and numerous districts. Governors and District Governors, declared curfew "until a further order is made". Regarding the provisions 11/c and 32/ç of the Act on Special Provincial Administration dated 1949, which have existed since the day the Act came into force. These curfew measures were only announced on the website of the Governors and District Governors in written form, but were not subject of an official announcement. The curfews were also made public to the local people by vocal announcement.

When the wording of these two provisions, which have existed since 1949, are examined, it can be seen that they do not include any measures as curfew: "Governor has the obligation and duty to provide peace and security (...), public wellbeing

\footnotetext{
12 Art. 23: (1) Freedom of residence may be restricted by law for the purpose of preventing crimes, promoting social and economic development, achieving sound and orderly urbanization, and protecting public property.

(2) Freedom of movement may be restricted by law for the purpose of investigation and prosecution of an offence, and prevention of crimes.
} 
and preventive law enforcement authority within the provincial borders" (Article 11/c-32/ç). Besides, the authority to take measures given to governors by the Act of State of Emergency and Martial Law was extended to the district governors regarding this act of state of normalcy. But the addressing of curfew measures anticipated under the state of emergency, without first declaring the state of emergency by following the appropriate constitutional procedures and without referring to the Act of Emergency which becomes applicable under such conditions, is in itself unconstitutional (Göztepe 2017, p. 119 ff.).

The question to be asked here is, why is this unlawful procedure being referred? While the legal framework and grounds for the state of emergency concept have been set at both constitutional and legal levels, the executive body is given relatively broad authority, and therefore there is no reason a one-party government with a parliamentary majority should fear a decision of rejection. Why has the constitutional procedure been deviated from and referred to as a pseudo-legal parallel method unprecedented in the history of Turkey?

Regarding the facts, the answer can be given in this way: In the procedure anticipated by the constitutional order, the authorised bodies, measures to be applied and cooperation facilities between bodies are specified in a limited way. However, from what can be obtained through the news in the press, in the cities and districts where curfew was declared, civil authority's cooperation with military forces and ordinary law enforcement offices is being actualised within uncertain margins, in a way that was not anticipated within the legal framework. Military forces are holding operations in cities, even though military operations in city centres should only be legitimised under officially declared martial law in regards to the principle of proportionality and fundamental rights in Article 15 of the Constitution. Under these circumstances, we can state that we have faced in this time period a "deconstitutionalisation" of the emergency regime.

Also the Constitutional Court and the European Court of Human Rights (ECtHR) were involved in the judicial review of these curfew measures, but both of the judicial bodies disposed themselves of the constitutionality/legality matter of the curfew measures. After their applications were rejected by the Constitutional Court ${ }^{13}$ the applicants called the ECtHR ${ }^{14}$, but the Strasbourg Court rejected the applications with the result that the Turkish Government had to provide the Court with certain factual information about the curfew situation and its consequences for the people concerned. At the end the ECtHR decided not to apply Rule 39 (interim measures) of its Rules of Court, because the elements at its disposal were insufficient. The Court asked the applicants to keep it informed of any subsequent developments. Lastly, given the gravity of the situation, the Court relies on the Government to take any necessary steps to ensure that physically vulnerable individuals can have

13 No. 2015/15266 (11.9.2015); 2015/19545 (22.12.2015); 2015/19907 (26.12.2015); 2015/20218 (31.12.2015); 2016/43 (8.1.2016); 2015/20376 (20.1.2016); 2016/1652 (29.1.2016); 2016/1905 (3.2.2016); 2016/2602 (12.2.2016); 2016/3349 (24.2.2016); 2016/3646 (29.2.2016); 2016/3475 (29.2.2016); 2016/5993 (5.4.2016); 2016/9400 (23.5.2016).

${ }^{14}$ See among others Yavuzel and Others v. Turkey, Application No. 5317/16; Irmak v. Turkey, Application No. 5628/16; Karaduman and Çiçek v. Turkey, Application No. 6758/16. 
access to treatment if they so request. The Constitutional Court again proceeded with the rejection of the applications without reviewing at the first stage the legality/ constitutionality of the measures since they were introduced in the absence of the declaration of the state of emergency. Retrospectively, this was an obvious signal of self-restraint by the Constitutional Court which would be repeated almost one year later after the attempted coup d'état in 15 July 2016.

\section{The Final Break with the Principles of the Constitutional State}

On the night of July 15,2016 , an attempt was made to carry out a military coup d'état, which was thwarted by the government within three days. Shortly afterwards, the preacher Fetullah Gülen, who lives in the USA, was declared responsible for the coup attempt and his followers were immediately persecuted. On July 21, 2016 a state of emergency was declared by the Council of Ministers ${ }^{15}$ which ended after two years on July 19, 2018. Turkey also made immediate use of the derogation possibilities by notifying the $\mathrm{UN}^{16}$ and the Council of Europe ${ }^{17}$. After this proclamation 32 emergency decrees in total were published. The crucial difference between these decrees compared to those in the 1990s is that the abstract act of norm-making through the decrees was accompanied by the executive act in the same document. That means that the people who were dismissed from the civil service were not notified through a concretising individual executive act on the basis of the abstract decree norm, but their full names were published as an appendix of the decrees in the Official Gazette. This practice has had the effect that the regular legal remedies were abolished, so the dismissed civil servants have neither the possibility to directly turn to the administrative courts nor the Constitutional Court.

Despite the new mode of decrees the dismissed civil servants called on the Constitutional Court hoping that the Court would declare this practice unconstitutional on the basis of its former jurisdiction summarized above. But against expectations, the Constitutional Court has given up its above mentioned, long standing leading principles to protect the rule of law even in times of emergency regimes and has ruled that it does not have the powers to test the emergency decrees on the ground of Art. 148 par. $1^{18}$. First of all, it must be noted that the new jurisprudence of the Constitutional Court contains contradictory arguments in each paragraph. The Court first begins with the constitutional framework of the state of emergency and repeats the constitutional norms as well as the own settled jurisprudence, but without contextually interpreting them in their entirety. The Court sees the sense of these constitutional rules "in the protection and continuity of the democratic legal system and emphasizes that the enhanced powers of the executive are nevertheless subject to legislative and judicial control, i. e. the principles of the constitutional state" (\$3-4).

\footnotetext{
15 Decision No. 2016/9064 (published in the Official Gazette on July 21th, 2016).

16 UN ICCPR, Reference: C.N.580.2016.TREATIED-IV.4 (21.07.2016).

17 Notification de Communication, Council of Europe, Ref. JJ8190C Tr./005-192 (25.07.2016).

18 E. 2016/166, K. 2016/159; E. 2016/167, K. 2016/160 (12.10.2016); E. 2016/171, K. 2016/164, E. 2016/172, K. 2016/165 (2.11.2016).
} 
Referring to Art. 148 par. 1, third sentence of the Constitution, that no action can be brought before the Constitutional Court against the state of emergency regulations and the minutes of the Constituent Assembly from 1982, the Court claims that the legislature had only decided in favour of legislative control in a state of emergency $(\$ 14-16)$. From this the Court concludes that it is itself due to Art. 6 par. 3 sentence 2 of the Constitution ("No one and no body may exercise powers of the state, which does not emerge from the Constitution") and of Art. 148 (\$17-18) it was not granted to be the judicative supervisory body for the executive branch in the state of emergency. Even this short sentence turns out to be the first step towards selfabandonment of the Constitutional Court as guardian of the rule of law in Turkey. At the same time, the Court does not raise the question of how the executive could deal with the extended powers to restrict fundamental rights and freedoms and that in the parliamentary system the political agreement of the executive with the parliamentary majority cannot really mean political control.

With regards to its previously established case-law, the Court emphasizes that the earlier case-law examined the derogations for their temporal, territorial and substantive conformity with the grounds for the state of emergency and its proportionality. However, this review required a substantive review of the ordinances, which was not provided for in the Constitution (\$21-22). Thus, the Court basically concludes that, although the executive branch has constitutional limits in a state of emergency, its judicial control is impossible even in a state governed by the rule of law and that it has to dismiss the action itself on the grounds of lack of jurisdiction (\$27). With this succinct argumentation, the Constitutional Court not only abandoned its established case law in only two paragraphs, but also made the unamendable principles of the Constitution in Art. 2 obsolete and meaningless. For on the one hand, to exalt the judiciary as a key element of the constitutional state and, on the other hand, to interpret the Constitution only on the basis of a single article, without considering the entirety and spirit of the Constitution, is, to put it mildly, a poor testament of a long-traditioned Court.

The direct effect of this jurisdictional change is that the executive power under the chairpersonship of the state president could not be bound by any further institution. Since the parliamentary majority was under the control of the governing party, the Constitutional Court as the only independent, politically not bounded state institution escaped its crucial responsibility and thus it also abandoned the rule of law. As a result of this verdict, the executive branch issued a total of 32 decrees with contents that as well as abolishing all constitutional guarantees which had nothing to do with the reason for, objective or time frame of the state of emergency regime. Just to give a few examples: Immediate dismissal from public service without trial (for life, without payment of social security contributions and pension entitlement) by which approximately 126,000 persons have been affected. Also, no academic activity such as the habilitation procedure is permitted outside the university; no possibility of returning to the original university in the case of discharge and reinstatement; cancellation of work licences (e.g. teachers); a ban on leaving the country and cancellation of passports, including those of spouses; uniform requirements for all pre-trial detainees when they appear before the court. The colour of the uniform differs depending on the offense with which the inmates are accused. Finally, 
the economic measures should also be mentioned, which represents a shift from a normative state to a prerogative state in the sense of Ernst Fraenkel's distinction ([1941] 2017). According to the emergency decrees the intervention in property rights through executive acts without any judicial decision is also allowed. In this regard, almost 900 companies were closed and their assets, worth more than 10 Billion Euros in total, were seized and transferred to the administration of the state. Moreover, the Turkish Property Fund (Türkiye Varlık Fonu), which administers these transferred assets, was authorized to sell transferred assets without the requirement of a court verdict proving the guilt of the former owners.

Concluding, there are no effective legal remedies against these measures. An organized stalling tactic or, in Bracher's words, a "controlled confusion" (1962, p. 169) characterizes the current legal system. The establishment of a commission to review the measures under the state of emergency on 23 January 2017 did nothing to change this finding. Because the commission consists of only 7 members, who are supported by 230 administrative staff persons. Legal remedy against the decisions of the commission leads initially to the administrative courts in Ankara (19th and 20th Administrative Court), and then to the Constitutional Court. Only after that, the ECtHR might be addressed. The constitutional principle of a reasonable duration of proceedings is thus obviously abandoned with this practice.

\section{Conclusion}

At this point we should rethink the concept of constituent power under the conditions of intra-legal state of emergency regimes. Our historical conception of constituent power relies on the idea that it appears at moments which illustrate a revolutionary break in the constituted political order and can therefore exist without any legal boundaries and is an extra-legal vacuum for new forces. But we recognize that in the last two decades in the modern world, that also Lockean state of emergency regimes have leant towards a constituent power regime and that they are even remaining within their existing constitution. Political developments since 9/11 in favour of populist governments which have invented the "post-truth" for themselves, as well as many judicial decisions by national and international courts dealing with the judicial consequences of originally intra-legal state of emergency measures which have gone far beyond the boundaries of the constitutional system, lead us to think about a new nature the constituent power.

We should remember that the sovereign dictatorship is in the truest sense a retrospective historiography which is unable to set any limits on the executive, which is in action and has absolute power. The fate of an executive with absolute power is determined or defined as such only after the success of the state of emergency. In the event of failure, one would have to resort again to the normative framework of the constitutional order.

The current developments all over the world and especially in Turkey shows us that the deliberate self-restraint of constitutional institutions leads to a creeping, non-revolutionary shift to a new constituent power by the constituted institutions. The regular work and functioning of the legislative branch disappears in favour of 
the executive in an unrestricted manner. That is what I call the permanency of the exceptional $^{19}$.

Since the extensive constitutional amendments on April 16, 2017, the governmental system in Turkey has shifted to an authoritarian presidential system without any effective checks and balances. Even the unamendable articles 1, 2 and 3 which are still in effect in the Turkish Constitution can only be defined as "semantic" in terms of the classification of constitutions by Karl Loewenstein as normative, nominal, and semantic. In regards to Loewenstein the semantic constitution is "fully applied and activated, but its ontological reality is nothing but the formalization of the existing location of political power for the exclusive benefit of the actual power holders in control of the enforcement machinery of the state. (...) Instead of serving for the limitation of political power, it has become the tool for the stabilization and perpetuation of the grip of the factual power holders in the community. The peaceable, non-revolutionary change in the location of political power is impossible" (1965, p. 149).

At the end, it seems to be a deeply political decision to accept the emergency as a kind of "fact" which cannot be ruled by law or as a possibility to be enshrined by law. Joining the opinion of Ferejohn and Pasquino (2006, p. 347), in every modern democracy there are and should be politically accountable organs which have the competence to decide whether the invocation of emergency powers is necessary or not. Without debt, this decision-making process should also be regulated and under the revision of other balancing constitutional bodies. Any other factual, contra- and extra-legal conceptions obliterate the modern constitutional state and its principles and deserves only the name despotism.

\section{References}

Alford, Ryan. 2017. Permanent state of emergency. Unchecked executive power and the demise of the rule of law. Montreal: McGill-Queen's University Press.

Bracher, Karl Dietrich. 1962. Die Technik der nationalsozialistischen Machtergreifung. In Der Weg in die Diktatur. 1918 bis 1933. Zehn Beiträge, 151-174. München: R. Piper.

Ferejohn, John, and Pasquale Pasquino. 2004. The law of the exception: a typology of emergency powers. International Journal of Constitutional Law 2:210-239.

Ferejohn, John, and Pasquale Pasquino. 2006. Emergency powers. In The Oxford handbook of political theory, ed. John S. Dryzek, Bonnie Honig, and Anne Philipps, 333-348. Oxford: Oxford University Press.

Fraenkel, Ernst. 2017. The Dual State. A Contribution to the Theory of Dictatorship. Oxford: Oxford University Press. First published in 1941.

Frankenberg, Günter. 2010. Staatstechnik. Perspektiven auf Rechtsstaat und Ausnahmezustand. Frankfurt a.M.: Suhrkamp.

Friedrich, Carl J. 1957. The constitutional reason of state. Rhode Island: Brown University Press.

Göztepe, Ece. 2017. Ein Paradigmenwechsel für den Sicherheitsstaat. In Ausnahmezustand. Theoriegeschichte - Anwendungen - Perspektiven, ed. Matthias Lemke, 105-127. Berlin: Springer VS.

Lemke, Matthias. 2017. Demokratie im Ausnahmezustand. Wir Regierungen ihre Macht ausweiten. Frankfurt a.M.: Campus.

Locke, John. 1823. Two treaties of government. Prepared by Rod Hay for the McMaster University Archive of the History of Economic Thought

${ }^{19}$ See for other country examples regarding the permanency of the exception (Alford 2017; Mehozay 2016). 
Loewenstein, Karl. 1965. Political power and the governmental process. Chicago: University of Chicago Press.

Mehozay, Yoav. 2016. Between the rule of law and states of emergency. The fluid jurisprudence of the Israeli regime. New York: SUNY.

Nippel, Wilfried. 2011. Carl Schmitts „kommissarische“ und ,souveräne“ Diktatur. Französische Revolution und römische Vorbilder. In Ideenpolitik. Geschichtliche Konstellationen und gegenwärtige Konflikte, ed. Harald Bluhm, Karsten Fischer, and Marcus Llanque, 105-139. Berlin: Akademie Verlag.

Pasquino, Pasquale. 2013. Between Machiavelli and Carl Schmitt. Remarks on Rousseau's dictatorship. Storia del Pensiero Politico 1:145-154.

Schmitt, Carl. 1994. Die Diktatur, 6th edn., Berlin: Duncker \& Humblot.

Straumann, Benjamin. 2016. Crisis and constitutionalism. Roman political thought from the fall of the republic to the age of revolution. Oxford: Oxford University Press. 